\title{
Diário da Tarde e Cruzeiro: querelas entre anticlericais e católicos no Paraná (1931-1932)
}

\author{
Diário da Tarde and Cruzeiro: squabbles between anti-clericals \\ and catholics in Paraná (1931-1932)
}

Nevio de Campos ${ }^{1}$

\section{RESUMO}

Este artigo objetiva discutir o confronto entre católicos e anticlericais no Paraná do início da década de 1930. Apoia-se na História Intelectual, particularmente na acepção de que a ação dos intelectuais caracteriza-se pela participação na vida pública, criando escolas, centros culturais, universidades, jornais. Neste texto, os grupos analisados exerceram suas funções intelectuais ao fundarem e dirigirem o jornal vespertino anticlerical (Diário da Tarde) e o matutino católico (Cruzeiro). À luz dos editoriais e notas dos referidos jornais é possível afirmar que sob o pano de fundo da disputa entre católicos e anticlericais, buscava-se catolicizar ou secularizar a opinião pública paranaense.

Palavras-chave: Intelectuais. Imprensa. Católicos. Anticlericais. História Intelectual.

\section{ABSTRACT}

This article discusses the confrontation between Catholics and anti-clericals in the state of Paraná during the 1930s. It bases itself on Intellectual History especially with the meaning that the intellectuals' actions was characterized by taking part in public life, establishing schools, cultural centers, universities, newspapers. The groups analyzed in this text exercised their intellectual functions when they founded the evening anti-clerical newspaper (Diário da Tarde) and the morning Catholic one (Cruzeiro). In light of the editorials and notes of the above mentioned newspapers it is possible to state that what the newspapers aimed at was to catholicize or secularize the public opinion in Paraná with the dispute between Catholics and anti-clericals as the background.

Keyword: Intellectuals. Press. Catholic. Anticlericals. Intellectual History.

1 Doutor em Educação, na Linha de Pesquisa de História e Historiografia da Educação pela Universidade Federal do Paraná(2006); Mestre em Educação, na Linha de Pesquisa de História e Historiografia da Educação pela Universidade Federal do Paraná (2002); Bacharel e Licenciado em Filosofia pela Universidade Federal do Paraná (1999). Professor do Programa de Pós-Graduação em Educação e Professor no Mestrado em História da Universidade Estadual de Ponta Grossa. Área de pesquisa: história, intelectuais, discurso e educação. Pesquisador Produtividade CNPq, Nível 2. 


\section{Introdução}

$\mathrm{Na}$ historiografia brasileira há diversos estudos a respeito do confronto entre católicos e anticlericais/livres-pensadores, ${ }^{2}$ como, por exemplo, Brasil: igreja contra estado (crítica ao populismo católico), de Roberto Romano e $A$ elite eclesiástica brasileira de Sérgio Miceli. No Paraná, existem várias pesquisas que trataram das querelas de católicos e seus adversários, entre final do século XIX e século XX, entre elas destaco as obras Idéias em confronto de Carlos Alberto Balhana, Intelectuais e igreja católica no Paraná (1926-1938) de Névio de Campos, Educação, cultura e modernidade: o projeto formativo de Dario Vellozo (1906-1918) de Maria Lúcia de Andrade, Corvos nos galhos das acácias: o movimento anticlerical em Curitiba (1896-1912), de Tatiana Marchette e Clotildes ou marias: mulheres de Curitiba na Primeira República, de Etelvina Trindade.

Na historiografia da educação há um número significativo de pesquisa que analisou o lugar da educação nos projetos societários propugnados por católicos e defensores da educação laica. Nessas abordagens é recorrente a disputa entre os signatários da educação católica e da educação laica, cujos representantes se consubstanciaram no clero e lideranças católicas (Dom Leme, Alceu Amoroso Lima, Pe. Leonel Franca, etc.) e no grupo da Escola Nova (Anísio Teixeira, Fernando de Azevedo, Lourenço Filho, Darcy Ribeiro, etc.). O rol de pesquisa é extenso, entretanto, menciono a obra Molde nacional e fôrma cívica de Marta Carvalho (1998), na qual se discute a atuação de católicos e grupo da Escola Nova na Associação Brasileira de Educação.

Em relação ao contexto paranaense, há um número amplo de estudos que debate a ação de intelectuais que defenderam a conformação da educação a partir das cosmovisões metafísicas católicas ou da filosofia/ciência modernas, dentre os quais faço referência a obra intitulada Intelectuais, educação e modernidade no Paraná, organizada por Carlos Eduardo Vieira (2007a) - na qual um conjunto de pesquisadores apresenta resultados de suas investigações sobre educação nesse estado, no período de 1886 a 1964.

Em minha trajetória acadêmica tenho problematizado a presença dos católicos no debate da educação, enfatizando análises sobre sua ação no Paraná durante a primeira

\footnotetext{
2 As terminologias usadas pela historiografia para adjetivar o grupo que se contrapunha aos católicos são variadas. Tal constatação expressa a complexidade de qualquer tentativa teórica de agrupar indivíduos em determinados projetos que guardam alguma identidade comum. Toda tentativa de estabelecer um modelo interpretativo/explicativo acaba por simplificar a própria realidade empírica. No entanto, é preciso estabelecer um modelo, um conceito. Em geral, o grupo anticlerical paranaense se denominava livre-pensador. Na literatura historiográfica é utilizada, com certa freqüência, a acepção anticlerical para definir aquele grupo que assumia uma posição contrária ao clero, portanto não se tratava de uma postura contrária à religião. Assim sendo, ao longo deste texto utilizo os termos anticlericais e livres-pensadores para adjetivar o grupo do Diário da Tarde.
} 
metade do século XX. As pesquisas realizadas indicam que os católicos estabeleceram inúmeros jornais e revistas, centros culturais e intelectuais, como por exemplo, o Círculo de Estudos Bandeirantes (1929), a Faculdade de Filosofia, Ciências e Letras do Paraná (1938), Faculdade Católica de Filosofia de Curitiba (1950) e Universidade Católica do Paraná (1959). Em tais investigações, cujo recorte privilegiou a educação, busquei associar os projetos formativos católicos à ação da Igreja Católica que objetivava garantir a presença da doutrina religiosa na conformação da cultura do mundo moderno.

Neste texto, por um lado, o recorte é mais específico, pois tem por objetivo reconstituir o confronto entre o diário matutino católico (Cruzeiro) e o vespertino anticlerical (Diário da Tarde), ao longo do final de 1931 e início de 1932. Por outro, é mais amplo, porque não faz recorte estritamente na temática educacional. A rigor, o problema central consiste em debater as posições de tais jornais, buscando evidenciar que as publicações desses periódicos (marcadas por notícias sensacionalistas, acusativas, polêmicas, escandalosas e agressivas), eram editoradas sob o pano de fundo da disputa entre duas visões societárias divergentes.

\section{Diário da Tarde: estratégia sensacionalista para criticar a Igreja Católica}

No dia 29 de outubro de 1931, o jornal Diário da Tarde lançou a acusação ao Pe. Miele de que se envolvera com uma mulher casada, isto é, negou o voto de castidade e cometeu adultério. ${ }^{3} \mathrm{Na}$ edição do referido dia, estampou-se em letras destacadas (tamanho grande, negrito e minúsculo), no alto e meio da primeira página, o título "A Santa Madre Igreja conspurcada por um ministro Indigno de sua ordem clerical". Na sequência, em forma de subtítulo, ainda em letra destacada (tamanho menor do que o título, minúsculo e negrito) arrematava: "ouvistes que foi dito aos antigos: não cometerás adultério"... Antes da descrição da própria denúncia, os jornalistas ressaltaram em forma de subtítulo, também com letra destacada (tamanho menor do que o subtítulo anterior, negrito e maiúsculo) que "a reportagem do 'Diário da Tarde' desenvolverá a sua ação, desassombradamente, até ver punido o padre que denegriu um lar, roubou a honra de um homem de bem e traiu os cânones sagrados da límpida moral religiosa de Nosso Senhor Jesus Cristo" (DIÁRIO DA TARDE, 29 out. 1931, p. 1).

Em 1899, foi criado o jornal Diário da Tarde. Naquele momento, a principal motivação foi estabelecer uma postura de oposição ao jornal A República (fundado em 1886), que professava o discurso oficial do governo do Paraná. O periódico Diário da Tarde, de

3 No item intitulado Diário da Tarde e Cruzeiro: querelado e querelante será descrita em detalhes a acusação sobre Pe. Miele. 
impressão diária, manteve-se em circulação até 1975. Em 1931, o referido jornal estava no trigésimo segundo ano de circulação, sob a gerência de Aguilar Moraes e direção de Rodrigo de Freitas. Seu endereço de redação, administração e oficina era a Rua Marechal Deodoro, 65, centro da capital do Paraná.

De acordo com Luiz Carlos Ribeiro (1985, p. 21), "tendo em sua linha editorial a preocupação com as notícias inéditas (o furo) e com certo sensacionalismo - pouco comum na imprensa local acostumada com transcrição de jornais do Rio - o Diário cobria com riqueza o cotidiano policial da cidade". De acordo com Juliana Pretto (2006), o sensacionalismo está na natureza da notícia, pois na verdade toda notícia, ainda que não queira ser sensacionalista, acaba tendo um aspecto sensacional à medida que é concebida para surpreender ou provocar o leitor. Para a autora, "o sensacionalismo parece estar relacionado à origem do jornalismo, à sua própria história, ou até mesmo à própria natureza da notícia" (PRETTO, 2006, p. 9). Para ela, é possível "afirmar que o tema das notícias é o critério usado pelos autores para definir as publicações como sensacionalistas, ou seja, são consideradas sensacionais notícias sobre acidentes, escândalos, assassinatos e crimes violentos de maneira geral" (PRETTO, 2006, p. 10).

Essa tendência a publicar notícias com forte teor emocional e moral, capaz de provocar no leitor sentimentos de amor ou ódio, expressa de maneira precisa as matérias veiculadas pelo Diário da Tarde a respeito de Pe. Luiz Gonzaga Miele.

Na edição de número 11.008, uma quinta-feira, do dia 29 de outubro de 1931, à primeira página assim pronunciava-se:

A reportagem do DIÁRIO DA TARDE, visando sempre desenvolver uma ação social de acordo com suas normas e tradições de publicismo objetivo, vem, hoje, abordar com minúcias, um caso que, sem dúvida, fará pasmar o mundo católico paranaense e escandalizar, por certo, até o próprio demônio, se de fato ele existe além do símbolo (DIÁRIO DA TARDE, 29 out. 1931, p.1).

A exposição do referido periódico indica alguns aspectos importantes do jornalismo moderno, como por exemplo, o compromisso com a publicização de informações de interesse público e com a verdade (publicismo objetivo). Tais fundamentos do jornalismo são usados para justificar a ação empreendida pelo Diário da Tarde. Ao modo peculiar do jornalismo que promovia reação apaixonadas no leitor, a matéria procurava marcar sua preocupação sensacionalista com o título e subtítulos já indicados nas páginas anteriores deste texto.

Em seguida, assevera que: 
A missão do jornal moderno não pode ser outra. Há os espíritos bisonhos e assombrados que exigem da imprensa apenas uma atuação incolor, qualquer coisa que não diga nada e que nada corrija ou transforme, para que os ouvidos castos da grande burguesia não sofram as arremetidas dos acontecimentos ruidosos e do escândalo. (DIÁRIO DA TARDE, 29 out. 1931, p. 1).

Essa passagem explicita a preocupação do Diário da Tarde com a crítica social. De acordo com Luiz Carlos Ribeiro (1985, p. 21), “de composição liberal, apresentou-se durante quase todo o período pesquisado [1899-1920], como um jornal de oposição. Guardando uma relativa autonomia do governo, abria suas páginas a toda crítica ao mau uso da coisa pública". Em nossa avaliação, a perspectiva desse jornal, indicada no período de análise de Ribeiro, pode ser estendida ao contexto do início da década de 1930, no qual, por um período de dois meses, o escândalo envolvendo a Igreja Católica ganhou espaço nas suas edições. A associação do periódico ao movimento liberal evidencia a preocupação em defender os velhos princípios apregoados pela vertente filosófica e política do liberalismo, particularmente o direito à liberdade. Outro aspecto importante a se destacar do fragmento de Ribeiro é o conceito de coisa pública, pois se o jornal tinha preocupação com a crítica ao mau uso da res publica é passível de sustentar um sentido ampliado dessa acepção. Desse modo, as atividades de diferentes instituições sociais estariam envolvidas com a coisa pública, particularmente a ação das lideranças católicas. Da mesma forma, a imprensa estaria incluída no conjunto de instituições responsáveis pelo uso da coisa pública.

O referido jornal destaca a noção de missão social do jornalismo/jornalista, isto é, do próprio intelectual, na acepção moderna, pois "o nascimento dos intelectuais é correlato à secularização da sociedade, da política e da cultura no continente europeu" (LECLERC, 2005, p. 28). Ademais, sustenta Leclerc (p. 28), "os intelectuais estão ligados à modernidade, isto é, ao secularismo, ao pluralismo religioso, ao nascimento das liberdades de pensamento e de publicação codificadas no final do século XVIII pela Revolução Francesa, sob a expressão 'direitos humanos'".

Por outro lado, o jornal denunciava a postura dos periódicos que se posicionavam em favor do poder instituído ou tinham uma ação conivente. Tal prática "é uma forma expedita para que os jornais, com o silencio, se tornem cúmplices indiretos de misérias e delitos por outrem praticados" (DIÁRIO DA TARDE, 29 out. 1931, p. 1). Na edição de 30 de outubro foi feita dura crítica aos jornais O Dia e Gazeta do Povo ao indagar-se: "com que direito [...] falam do Sr. Chefe de Policia, para opor desmentido à informação por nós ventilada sobre o pedido de garantia de vida que o padre foi solicitar na Central de Polícia?". A informação citada diz respeito ao pedido de proteção solicitada ao delegado, pelo Pe. Miele, pois a suposta amante teria escrito um bilhete ao prelado informando que estava "temerosa de que o seu ultrajado 
esposo assassine o seu vil rival" (DIÁRIO DA TARDE, 30 out. 1931, p. 5). Os jornais O Dia e Gazeta do Povo teriam solicitado ao delegado (João Grabski) que desmentisse o furo noticiado pelo Diário da Tarde. Em seguida, pronuncia-se: "mantendo-se na cômoda atitude de neutralidade, tão do sabor dos desfibrados, permitiu-se a 'Gazeta do Povo' a liberdade de criticar a conduta do 'DIÁRIO DA TARDE', neste caso escabroso" (DIÁRIO DA TARDE, 30 out. 1931, p. 5). Em tom contestatório encetou: "façam se quiserem a defesa deste fauno de batina, mas não exorbitem deste direito, pois, não vacilaremos em colocar cada um no seu devido lugar...” (p. 5).

A função intelectual do jornalismo moderno seria postular uma crítica ao poder estabelecido tal qual imaginavam os responsáveis pelo Diário da Tarde. É possível afirmar que a pretensão do grupo desse periódico é corolário do anseio dos princípios da modernidade. Fica clara então a hipótese de que "o desafio contemporâneo está em realizar a utopia na modernidade, tal como ela se apresenta a partir do século XIX. Isto é, fazer da modernidade uma experiência baseada na ciência e na técnica, vivida a partir da Europa, não mais em ilhas ou terras distantes" (PAZ, 1994, p. 7) fazia enorme sentido ao grupo desse vespertino. A rigor, no entendimento daqueles jornalistas, "mais do que sonhos insólitos, utopia e modernidade configuram o real oitocentista" (PAZ, p. 7).

Um dos elementos da Revolução Francesa caro aos intelectuais modernos consistia na pretensão de "expandir o ideal revolucionário de liberdade, liberdade dos povos, liberdade como valor universal” (PAZ, 1994, p. 9). De modo semelhante, o grupo do Diário da Tarde apregoava a liberdade como valor fundamental da humanidade. De acordo com Leclerc (2005, p. 30), "o pluralismo religioso contribuiu para o nascimento do espírito de tolerância, o aparecimento de discursos globais, leigos, neoreligiosos, pararreligiosos e não-religiosos desde o século XVII e sobretudo no XVIII". É nesses termos que, no início da denúncia, o vespertino paranaense ressaltou a verdade e o direito público à informação como pressupostos do jornalismo moderno. O que se mostra é que "o jornalista, que era mediador, parece transformado num intelectual, no novo tipo de intelectual de mídia. Ou ainda: o novo intelectual é necessariamente mediático" (LECLERC, 2005, p. 86).

Em nossa avaliação o Diário da Tarde não pode ser tratado como um periódico preocupado apenas com notícias sensacionalistas. Neste texto, defendemos a hipótese de que o furo de notícias polêmicas e escandalosas, particularmente o episódio envolvendo Pe. Miele consistia em uma estratégia para exercer sua função social: crítica. Assim sendo, pactuamos com Leclerc (2005, p. 40), pois "eles [intelectuais] entregam-se a polêmicas incessantes e operam, no seio de seu pequeno grupo, rupturas de impacto. Sua atividade de escrita é marcada por um ativismo crítico". Além disso, acrescenta o autor (p. 4), "ideólogos do devir histórico e do movimento político, eles mostram-se, uns em relação aos outros, concorrentes e críticos ferozes". 
Pelo exposto, pode-se afirmar que o Diário da Tarde, jornal que nascera com a pretensão de exercer a crítica ao poder instituído, seja ele civil (Estado) ou eclesiástico (Igreja), nas suas edições do final de 1931 encampou uma ação de confronto direto à Igreja Católica. Por meio da notícia que promovia horrores entre os leitores, deixando-os tomados pelos sentimentos de amor ou ódio, levava ao cenário público a disputa entre clericais e anticlericais.

\section{Cruzeiro: paladino da Legião Paranaense de Boa Imprensa}

A ação da Igreja Católica no Paraná ganhou contornos precisos a partir do final do oitocentos com a criação da Diocese de Curitiba. Em seguida, diversas ordens religiosas passaram a ser instaladas em terras paranaenses. As frentes de atuação dos católicos eram variadas, entre as quais destaco a fundação de colégios femininos e masculinos, hospitais, seminários, conventos, periódicos, centros culturais. Conforme Balhana (1981), Trindade (1996), Marchete (1999), Andrade (2002), na virada do século XIX ao XX houve confronto expressivo entre clericais e anticlericais, travado sob a orquestração de Dario Vellozo (anticlerical) e Pe. Desidério Deschand.

Na década de 1920, conforme Campos (2010), a Igreja Católica contou com a organização do laicato católico no Paraná, pois estabeleceu o Centro Literário São Luiz (1924), a União de Moços Católicos de Curitiba (1926), a Revista A Cruzada (1926), o Círculo de Estudos Bandeirantes (1929). Na década seguinte, foram criados diversos periódicos (Cruzeiro, $\mathrm{O}$ Alvor e O Luzeiro), bem como a Faculdade de Filosofia, Ciências e Letras do Paraná (1938). Tais espaços culturais estavam sob o controle de lideranças intelectuais e políticas do Paraná, assim como de representantes do clero.

Segundo Névio de Campos (2010, p. 66-67), “os intelectuais católicos leigos no Paraná reagiram ao laicismo e propuseram como mecanismo de propagação dos valores católicos [...] a Imprensa Católica". De acordo com Romualdo Dais, essa ação estava vinculada à crença de que "[...] a imprensa católica deveria contribuir com a restauração social efetivando as seguintes tarefas: divulgar a doutrina social da Igreja, informar sobre as atividades dos inimigos e sobre os meios de combate já experimentados nas diversas regiões [...] (DIAS, 1993, p. 109). Nessa direção, sustenta Ramiro Oliveira (2010, p. 17) que "o movimento restaurador católico soube aproveitar o potencial da imprensa". Desse modo, acrescenta o autor, "as lideranças eclesiásticas e leigas reconheciam o valor dos jornais como instrumentos de intervenção social e realizaram diversos esforços para o surgimento de uma imprensa católica significativa no país" (OLIVEIRA, 2010, p. 17).

Desde 1926, o laicato católico paranaense atuou na direção de periódicos. Naquele momento, a Mocidade Católica Paranaense estabeleceu a Revista A Cruzada. Em 1931, a 
Legião Paranaense de Boa Imprensa fundou o Cruzeiro. Em 1935, a Associação dos ex-alunos do Instituto Santa Maria criou o jornal mensal O Alvor. Em 1937, o grupo católico estabeleceu o jornal mensal o Luzeiro. Entre 1926 e 1939, esses periódicos representaram um dos espaços de ação do laicato católico, embora cada jornal estivesse vinculado a instituições católicas diferentes.

Em 1926, no editorial da revista A Cruzada, o grupo católico apregoava que "quando vir a verdade insolentemente negada e a virtude cinicamente proscrita, não deixará esta revista de levantar a voz para defender a ambas, alumiando e alentando" (A CRUZADA, mar. 1926, p. 1). Além disso, "somos um pequeno grupo de moços entusiastas e destemidos que professamos de viseira erguida aquela Religião que, além de ser universal, é dos brasileiros" (A CRUZADA, mar. 1926, p. 1). Entre 1926 e 1930, A Cruzada, passou a ser um importante espaço de divulgação da moral católica e de contraposição aos adversários e inimigos da Igreja, "alumiando e alentando" a opinião pública paranaense.

Durante a década de 1920, a imprensa atrelada aos livres-pensadores, particularmente os jornais A Tarde e Diário da Tarde fizeram acusações de improbidade administrativa ao governo de Caetano Munhoz da Rocha (1920-1928). Os escritos jornalísticos do grupo livrepensador endereçavam fortes críticas ao vínculo existente entre os governantes do Paraná e a Igreja Católica. Tal combate destacava-se no governo de Caetano Munhoz da Rocha, no qual múltiplas obras católicas receberam subvenção estatal.

Os católicos, por sua vez, sustentavam que:

O espírito laicista, exaltado por diminuta corrente anticlerical, predominante no escasso elemento intelectual da época, não podia ver com bons olhos um homem impor-se na política regional a afirmar desassombradamente que era católico e invocar as bênçãos de Deus para sua obra de humano administrador (REVISTA DO CÍRCULO..., 1944, $352)$.

A passagem acima, escrita por Loureiro Fernandes, integrante do laicato católico paranaense, faz referência à trajetória de Caetano da Rocha. As objeções dos católicos às críticas dos jornalistas atrelados aos periódicos anticleriais ou que se denominavam neutros, expressam o ambiente das décadas de 1920 e 1930.

Os ataques desferidos contra os católicos, bem como as respostas dadas aos anticlericias se materializam em diferentes episódios. Desse modo, a denúncia a que nos referimos no primeiro item deste texto exemplifica o confronto entre os jornalistas católicos e anticlericais pela conformação da opinião pública paranaense. Sob a justificativa de uma razão imediata, suposto envolvimento de Luiz G. Miele com uma mulher casada, os dois 
grupos discutem suas principais teses em relação a diferentes temas correntes daquele contexto. Nesse caso específico, o Cruzeiro foi o principal órgão de resposta à acusação lançada pelo Diário da Tarde, pois o jornal católico pertencia à Legião Paranaense de Boa Imprensa, cujo presidente era o próprio Pe. Luiz Gonzaga Miele.4 Assim sendo, sob o pano de fundo da acusação noticiada pelo Diário da Tarde, o Cruzeiro publicava respostas que condenavam o grupo anticlerical e reafirmavam o compromisso da Igreja Católica com a verdade e com o bem.

O jornal Cruzeiro iniciou sua circulação em setembro de 1931, permanecendo até 31 de janeiro de 1932, quando foi suspensa sua publicação. Em 08 de setembro de 1931 teve início a publicação do Cruzeiro, diário matutino, propriedade e direção da Legião Paranaense de Boa Imprensa. A superintendência do jornal era ocupada por José Nicolau dos Santos. O referido matutino tinha sua oficina e redação à Rua XV de Novembro, 615. De acordo com sua nota de expediente, o jornal tinha agências e representantes em todos os municípios do Paraná. Não localizamos o contingente de impressão diária. Na nota há indicação de que o matutino poderia ser assinado por trimestre, semestre e anuidade.

No editorial da primeira edição foi apresentado o programa do Cruzeiro. Na denominação do grupo católico "inicia hoje a sua trajetória no meio cultural da imprensa este jornal - CRUZEIRO - paladino que se apresenta sem maiores credenciais que as do próprio direito de pensar e poder figurar ao Sol da Pátria comum" (CRUZEIRO, 8 set. 1931, p. 1). É interessante observar que o jornal católico defendia sua razão de ser em nome da liberdade de pensamento. Esse aspecto é uma condição importante à Igreja Católica, pois o regime republicano ao estabelecer a separação entre poder civil e poder eclesiástico também garantiu a liberdade àquela instituição religiosa. Se no Império estava sob controle do sistema do padroado, na República exerceu o direito de pensar, conforme apregoava o editorial de lançamento do Cruzeiro.

Em seguida, sustenta-se que,

corporizando o pensamento e o ideal programados na ação social da 'Legião Paranaense de Boa Imprensa', realidade que se fez manifesta aos olhos mais céticos dos companheiros, neste empreendimento, CRUZEIRO veio concretizar também o despreendimento e o esforço abnegado de todos os bravos batalhadores que se alistaram em prol desta boa causa (p. 1).

4 Luiz Gonzaga Miele nasceu em São Bernardo do Campo no dia 31 de maio de 1893. Concluiu sua formação filosófica e teológica em Paris. Em 1924, foi nomeado professor do Ginásio Paranaense, na seção internato, professor de lógica, psicologia e história da filosofia, o que evidencia a estreita relação entre Igreja e Estado no governo de Caetano Munhoz da Rocha. Em 1929, coordenou o processo de criação do Círculo de Estudos Bandeirantes (CEB), um órgão de estudo da doutrina católica que aglutinava lideranças políticas e intelectuais do Paraná. Padre Miele dirigiu o CEB até dezembro de 1932, quando se transferiu para São Paulo. 
A vinculação do Cruzeiro à Legião Paranaense de Boa Imprensa indica a separação entre legião da má imprensa e legião da boa imprensa. Ora, se os católicos representavam a boa imprensa, os anticlericais deveriam ser os protagonistas da imprensa ímpia. As avaliações dos católicos tinham a tendência de promover uma visão maniqueísta de todas as esferas da sociedade. Em primeiro lugar, associam tradição católica à verdade, ao bem, à verdadeira ética. Em seguida, qualificam seus adversários de protagonistas da mentira, da calúnia, do ódio.

Na avaliação do matutino,

CRUZEIRO raiou e se levanta agora, sem perigos de contrabalanços do evento, ao alto da reta a seguir, qual estandarte de confiante vitória, a infundir fé e coragem aos espíritos timoratos. Ele será também farol guiador, iluminando consciências ainda turbadas pela anarquia do tempo e por elementos interessados no continuar, com proveitos, a confusão reinante (CRUZEIRO, 8 set. 1931, p. 1).

Pela exposição acima, de maneira explícita o grupo católico indica que o jornalismo deverá ser a luz, capaz de elucidar a opinião pública paranaense. Salienta que as filosofias reinantes do século XX representam a anarquia intelectual e moral. Por outro lado, o remédio para essa doença seria a doutrina católica propagada pelo Cruzeiro, farol guiador e iluminador das consciências dos católicos e dos não católicos, pois "[...] o combate tinha como alvo dois tipos de inimigos: os externos e os internos. Os primeiros eram os inimigos da Igreja. Os segundos eram os próprios católicos que se deixavam impregnar pelo 'espírito acomodatício"' (DIAS, 1993, p. 110).

Na interpretação do jornal católico duas alternativas se apresentavam: a do amor e a do ódio. Nessa direção, apregoavam os católicos que:

Faltava, porém, para o apostolado do verdadeiro caminho, o intérprete almejado do sentir da alma do povo bom e pacífico, cuja feitura moral, profundamente religiosa e palpitante de rica seiva cívica, esculpira-se no mesmo concreto que cimentou o nascer e o desenvolver da nacionalidade (CRUZEIRO, 8 set. 1931, p. 1).

Por fim, em tom performativo o redator declarava que:

CRUZEIRO veio chamar a postos todos os legionários do bem, como clarinante soar do alarme que nasce espontâneo do fundo permanente 
do "substratum" cristão - vivo patrimônio das gerações do presente. Esse "alerta" nasceu e se estende ecoando aos rincões da Pátria, acordando e movimentando o instinto da raça indomável à evocação de ossadas gloriosas que dormem à vigília do "Cruzeiro do Sul" em terras do Brasil (p.1).

O editorial vinculava a ação católica à própria história do Brasil ao conclamar: "acorda agora o gigante brasílico para sua própria consciência livre. Revive no espírito novo do velho tronco plantado em Porto Seguro como marco inicial da vida nacional e dos direitos de Deus, da Pátria e da Família brasileira" (p. 1). O sentido de missão intelectual do jornalismo/jornalista é reafirmado pelos católicos, pois sustentavam que "não é possível transar com a crença, com a contextura moral que herdastes dos vossos contemporâneos!" (p. 1). Além disso, "seria indigno de corações que devem vibrar pela fé e pelo amor da Pátria una e tradicional, o cruzar de braços, o dormir em face do perigo que avança e se aproxima com a barbárie contemporânea". Na avaliação do Cruzeiro, tal barbárie estava "corrompendo costumes, espalhando licenciosidades, destruindo lares, expulsando o pudor e a dignidade, blasfemando o céu e a terra, profanando altares, incendiando templos e substituindo Deus pela besta" (CRUZEIRO, 8 set. 1931, p. 1).

Por fim, o editorial de apresentação do programa do Cruzeiro afirmava: "compete-nos também o direito de viver, de ser ouvidos, de exigir que nos sejam garantidos e respeitados direitos de pensar, não como párias e sim como brasileiros que somos, católicos na sua grande massa e conservadores de suas tradições na própria terra" (p. 1). O grupo católico iniciou e concluiu o editorial mencionando o direito de liberdade de pensamento, porém, acrescentou o adjetivo "compromisso com a verdade" ao conceito de livre pensamento. Tal inserção expressa a divergência de compreensão da acepção de liberdade entre livrespensadores e católicos.

Segundo Maciel de Barros, diferentes grupos defendiam a liberdade: "os liberais, clássicos ou cientificistas, por coerência doutrinária; os positivistas, porque ela é necessária à implantação definitiva da filosofia regeneradora; os católicos porque ela exprimiria uma lição evangélica" (BARROS, 1986, p. 228). Aqueles que se denominavam seguidores do liberalismo clássico compreendiam esse ideário como expressão dos direitos naturais, particularmente como decorrência da liberdade de consciência e de pensamento. De acordo com Barros (1986, p. 228), "[...] o liberal a concebe, ao menos em tese e enquanto direito de transmissão do pensamento e das opiniões, como praticamente ilimitada". Para o grupo católico, a liberdade representava o direito e o dever que todos têm de se dedicar à religião católica, ou melhor, era a liberdade de ensinar a verdade (doutrina católica) aos indivíduos.

Em síntese, ao longo deste item minha pretensão foi expor as diretrizes gerais do Cruzeiro, enfatizando o contexto paranaense que determinou o processo de organização do 
laicato católico. No próximo tópico discutirei alguns aspectos do confronto entre o matutino católico e o vespertino anticlerical.

\section{Diário da Tarde e Cruzeiro: querelado e querelante}

No dia 29 de outubro o vespertino denunciou que um representante do clero paranaense estava envolvido com uma mulher casada. Nessa edição não citou o nome completo do padre. Apenas informou pelo prenome (Luiz). Porém, enfatizou que "é um homem que trai a confiança de outro. Um homem que seduz a mulher do próximo. E esse homem é um padre, um ministro da Igreja Católica" (DIÁRIO DA TARDE, 29 out. 1931, p. 1). Na sequência afirmou que "a Igreja Católica não se culpa de um mau ministro. A religião de Jesus não sofre porque, em seu seio, procurando conspurcá-la, se aninhou um abutre, onde deverão estar somente as almas boas, os hodiernos apacentadores das ovelhas de Pedro e de Paulo" (DIÁRIO DA TARDE, 29 out. 1931, p. 1). Em detalhes, relatou ao leitor, como teve início o flerte do padre. Tudo teria iniciado quando "a esposa ingênua de um homem rural. A mãe carinhosa de dois lindos filhinhos [disse:] - Padre, eu pequei, sabe? Conseguirei a absolvição?" (p. 1). De acordo com o vespertino, Padre Luiz teria dito: "pecaste, minha filha. O teu pecado é grave... Eu preciso ajudar-te para o salvamento perante Deus. [...] Acalma-te. Amanhã é domingo. Sem que ninguém saiba virás ter comigo. E rezarás muito. Eu rezarei contigo, por ti (p. 1). No dia seguinte (domingo), após muita oração ele falou: "estás perdoada. Se fores minha amiguinha serás sempre perdoada... E uma mulher bonita nunca comete pecados mortais" (p. 1). Relatou o periódico que o prelado convidou a mãe de família para comparecer à igreja, novamente, no dia seguinte, para na companhia dele, fazer orações: "volte amanhã, a mesma hora, para rezar mais comigo, por si, ouviu? Sim - fez ela. E o padre apertou-lhe a mão demoradamente" (p. 1). Em seguida, repetiu: "eu vivo tão só, aqui com os meus santos... Volte amanhã. Tenha pena de um pobre padre, que vive só por Deus. E ela prometeu" (p. 1). Relata, por fim, que surgiam murmúrios sobre a conduta do referido padre, pois teria acontecido na pequena Prudentópolis, cidade do interior do Paraná. Porém, sobressaiam-se as vozes de que "o padre é um poço de virtudes. Não ouviu o último sermão dele sobre o pecado de adultério?" (DIÁRIO DA TARDE, 29 out. 1931, p. 5). Porém, "na faina da vida rural o esposo nem suspeitava o que lhe ia acontecer, o que fatalmente aconteceria, o que aconteceu depois" (p. 5).

Ao grupo católico do Paraná a notícia publicada no Diário da Tarde foi considerada difamação à trajetória desse sacerdote da Igreja. Desde o início até o final da circulação do Cruzeiro o grupo católico fez referência a tal episódio, destacando as ações jurídicas movidas contra os proprietários daquele jornal, bem como encetando uma série de respostas 
ao grupo anticlerical. A primeira manifestação ocorreu no editorial da edição de 30 de outubro de 1931, no qual o Cruzeiro estampou o título "restabelecendo a verdade".

Inicia o texto enunciando:

Dois vespertinos de ontem, ${ }^{5}$ em nota de escândalo, lançaram com títulos berrantes uma torpe exploração em torno do nome honrado do digníssimo sacerdote Luiz Gonzaga Miele, sobre pretendida desonra de um lar que é arrastado pelos noticiaristas à lama dos comentários infamantes, dos sedentos de escândalos de ruas (CRUZEIRO, 30 out. 1931, p.1).

Em continuidade afirma: "é de lamentar que fosse envolvido nas malhas da insidia e da injúria facílimas de estampar nas notas oficiosas de simples e superficiais reportagens, o nome impoluto do digno sacerdote que se procura denegrir sem provas das acusações que lhe são gratuitamente assacadas" (CRUZEIRO, 30 out. 1931, p. 1).

Além do mais, os católicos sustentam:

Tratando-se ainda mais de um sacerdote que reuniu sempre as mais brilhantes qualidades de espírito e de coração, estimadíssimo pela sociedade católica desta cidade e cujo proceder está acima da mais ligeira suspeita de incorreções morais, parece-nos que tais levianas e deslavadas notícias, pela sua forma e maneira com que foram veiculadas, não condizem com as normas da imparcialidade e justiça que devem pautar o critério dos que, responsáveis, escrevem para o público ledor (CRUZEIRO, 30 out. 1931, p. 1).

Ao laicato católico paranaense, Pe. Luiz Gonzaga Miele representava a principal liderança da própria organização católica. Em 1929, ele foi o idealizador do Círculo de Estudos Bandeirantes que, "no entender dos seus fundadores, seria uma sociedade cultural, não aberta e declaradamente religiosa, confessional. Poder-se-ia nas reuniões ventilar qualquer assunto, mesmo religioso, mas dentro dos princípios da ortodoxia religiosa, filosófica, científica, etc." (Correspondência do Pe. Miele a Loureiro Fernandes, 06 jul. 1956). De acordo com representantes do grupo católico (Loureiro Fernandes e Mansur Guérios), "o Círculo teve como principal ideador e fundador o Revmo. Pe. Luiz Gonzaga Miele” (REVISTA DO CÍRCULO..., 1934, p. I). Outro representante do laicato católico (Liguarú Espírito Santo), afirmava que "somente a compleição intelectual e moral de um Padre LUIZ GONZAGA

5 Os dois vespertinos eram Diário da Tarde e A Tarde. Neste texto explorei apenas as publicações do Diário da Tarde, pois não localizei na Seção Paranaense do Arquivo da Biblioteca Pública do Estado do Paraná, as edições do jornal A Tarde, do período do confronto entre clericais e anticlericais. 
MIELE, modelo do cidadão e do patriota, [...], ousaria esta 'entrada' pelo inóspito sertão do egoísmo, do utilitarismo e da mediocridade, características de épocas de crise e de decadência" (REVISTA DO CÍRCULO..., 1943, p. 552-553).

A exposição anterior indica a representação simbólica que Pe. Miele tinha entre o laicato católico. Dessa forma, o editorial do Cruzeiro concluía afirmando que:

Certos que nos achamos da perfeita inocência da vítima, arrastada à rua da amargura das dolorosas retaliações da dignidade e da honra, mal seguras nos tempos de misérias morais que atravessamos, não nos surpreendemos com tais investidas - aguardamos apenas, confiantes no pleno restabelecimento da justiça e verdade dos fatos. E a justiça não há de faltar aos que clamam por ela em abono de sua inocência. (CRUZEIRO, 30 out. 1931, p. 1).

Além do editorial, o matutino católico publicou duas notas na primeira página. A primeira fez referência ao episódio dos vespertinos e destacou que os católicos decidiram responsabilizar judicialmente os responsáveis pela acusação ao Pe. Miele. A segunda tratouse de uma moção do Círculo de Estudos Bandeirantes. Em reunião no dia 29 de outubro, foi redigido o manifesto católico que fora publicado na edição de 30 do referido mês:

Os sócios do Círculo de Estudos "Bandeirantes" [...] lançamos o protesto mais vibrante e veemente contra a exploração torpe, miserável e inaudita que se iniciou contra a honra e a dignidade de um dos sacerdotes mais puros que iluminam a sociedade, a família e a cultura do Paraná e do Brasil - o Exmo. e Revmo. Sr. Padre Luiz Gonzaga Miele. (CRUZEIRO, 30 out. 1931, p. 1).

O referido manifesto católico em defesa de Miele destacava que o ofendido:

Apóstolo insigne da santa religião de Cristo, modelo do cidadão e do patriota, jornalista de pulso, de cultura invulgar, e orador notável entre os notáveis, - foi ferido na sua honra, na sua pureza sacerdotal, de maneira extremamente injusta, infamante e cruel, por vil calúnia, que será destruída, - temos a segurança disso, - com a plena prova da inocência da vítima. (CRUZEIRO, 30 out. 1931, p. 1).

Por fim, os companheiros de Miele reiteravam que: 
Padrão de glória da Igreja Católica, ornamento preciosa da sociedade em que vive, o Exmo. e Revmo. Sr. Padre Luiz Gonzaga Miele não será atingido e sairá ileso, permanecendo sempre grande no coração dos bandeirantes, grande no coração dos paranaenses, grande no coração dos brasileiros, como estrela fulgurante de primeira grandeza, que iluminará àqueles mesmos que tão cruelmente o feriram em sua honra e em sua dignidade de sacerdote (p.1).

O Círculo de Estudos Bandeirantes, naquele momento, era presidido pelo Pe. Miele, portanto, o referido manifesto expressava a posição institucional desse centro cultural que promovia a doutrina católica, bem como a relação de amizade e dever de salvaguardar a imagem de seu principal idealizador. Tais observações evidenciam a afirmação de Bourdieu de que "os detentores do mesmo título tendem a constituir-se em grupo e a dotar de organizações permanentes [...] destinados a assegurar a coesão do grupo [...] e promover os seus interesses materiais e simbólicos" (BOURDIEU, 2002, p. 149).

Na edição de 30 de outubro, o vespertino Diário da Tarde publicou outros detalhes do escândalo envolvendo Pe. Luiz Miele. Com o mesmo título e subtítulos da publicação do dia anterior, escreveu: "em nossa edição de ontem muito de propósito, acusando o padre que desonrou o lar de um homem de bem, seduzindo-lhe a esposa, ocultamos o sobrenome do indecoroso fauno de batina, bem como a identidade das vítimas [...]" (DIÁRIO DA TARDE, 30 out. 1931, p. 1). O periódico enunciou os nomes completos do prelado, da suposta amante e do marido, respectivamente Pe. Luiz Gonzaga Miele, Lupercina Prado e Carlos Riffaud. Em seguida, os jornalistas informaram ao leitor que Pe. Miele enviou seus representantes à redação do Diário da Tarde para impedir a publicação de cartas que evidenciavam a relação adúltera:

Vendo-se perdido, enviou intermediários junto aos representantes da nossa reportagem, procurando suduzi-los por diversos modos, e oferecendo determindadas vantagens em troca das cartas que hoje publicamos, as epistolas que comprometem, definitivamente, o seu respectivo signatário (p. 1).

Sem obter sucesso, o próprio Pe. Miele foi solicitar à delegacia de polícia para interferir na edição do Diário da Tarde a fim de impedir a publicação das cartas trocadas entre ele e Lupercina Prado: "é assim que o padre Luiz Gonzaga entra na Central de Polícia, onde solicita a intervenção do dr. João Grabski, no sentido de obter da autoridade sua intervenção junto aos jornais, para que nada sobre o caso, fosse ventilado" (p. 1). Discorreu que a relação entre o padre e a mulher casada teve início em Prudentópolis, porém, continuou em Curitiba. Após isso, são publicados vários fragmentos de cartas trocadas entre Miele e Lupercina Prado, buscando evidenciar a afirmação de que "o padre prostituíra o matrimônio 
que Deus, na Igreja, pela voz da religião abençoou e que o juiz, em nome da lei, validou" (DIÁRIO DA TARDE, 30 out. 1931, p. 1).

Tais fragmentos das cartas pretendiam criar um efeito de verdade, bem como condenar a "alma libertina, que lhe importava o lar desfeito, a honra do esposo ultrajada, a virtude da mulher feita lodo e a dor de duas criancinhas, chorando pela mãe que as terá de deixar" (p. 1). Depois dos referidos excertos das missivas, pronunciava-se o jornal: "aí temos o retrato do sedutor, para que a Igreja Católica, quanto antes, o expulse de seu edificante convívio" (p. 1). Seguia: "com a documentação insofismável que possuímos, será inútil a lamúria dos que se agarram à batina enlameada do vil sedutor [...]" (p.1).

Em resposta ao editorial do Cruzeiro que se intitulava "restabelecendo a verdade", o vespertino indicava: "não mentimos. O escândalo nasceu do escândalo e dele só é responsável o autor da ignomínia, o sedutor de uma mulher casada, o padre que, renegando os ensinamentos cristãos, conspurcou um lar, roubou a honra de um matrimônio que, antes, a Santa Madre Igreja abençoara" (DIÁRIO DA TARDE, 30 out. 1931, p. 1).

Na edição de 31 de outubro, sob o título "solidariedade que conforta", o matutino católico publicou uma série de moções de apoio a Miele. Além disso, descreveu os nomes de personalidades públicas que prestaram homenagem ao representante do clero. Em nota, publicada na primeira página, em letra destacada, o Cruzeiro afirmou que a agressão encetada contra Miele resultou na "mais justa e veemente repulsa da sociedade curitibana, pelos termos injuriosos, gratuitamente atirados contra a honra e dignidade daquele digno e ilustre membro do clero paranaense" (CRUZEIRO, 31 out. 1931, p. 1). Entre as manifestações de solidariedade da sociedade católica, o periódico destacou a determinação de um conjunto de juristas que assumiu a coordenação da elaboração de um processo para ingressar ao Poder Judiciário a fim de responsabilizar os jornalistas do Diário da Tarde e A Tarde. Sobre esse aspecto, ressalta que "nada poderia ser mais eloqüente e confortador para o injuriado sacerdote, do que esse espontâneo gesto da ilustrada classe jurídica paranaense, que se traduz num protesto vibrante pela clamorosa injustiça que se consumou" (p. 1). É importante destacar que o redator procurar estabelecer um sentido de verdade ao indicar que a classe jurídica se mobilizou espontaneamente. A rigor, os juristas pertenciam aos diferentes órgãos da Igreja Católica, como por exemplo, Manoel Lacerda Pinto, Homero Batista de Barros, José Mansur Guérios, integrantes do CEB.

No artigo intitulado "o verdadeiro alvo", da edição de 31 de outubro, mencionou-se sobre os motivos que teriam determinado ao grupo anticlerical acusar Pe. Miele. O texto indica que: "percebe-se, nitidamente, nessa campanha insólita aberta por dois vespertinos desta capital, sem o necessário e sereno exame dos fatos, que não são dirigidos à figura eminente do intangível sacerdote da religião católica, Padre Luiz Gonzaga Miele [...]" (CRUZEIRO, 31 out. 1931, p. 1). Se não seria o referido padre o principal alvo da ação do grupo anticlerical, quem seria então? Na avaliação do Cruzeiro, "[...] os seus ataques irrefletidos e virulentos, - 
são antes às suas obras pelo saneamento moral de nossa sociedade, para cuja dissolução, desvirtuando os costumes, concorre com o máximo expoente [...] que denomina má imprensa" (p. 1). A ação social da imprensa católica, segundo o Cruzeiro, seria o principal objeto de ataque dos anticlericais, pois Miele, "fundador da Legião Paranaense, que tomou sobre os ombros a árdua e espinhosa tarefa de modificar e orientar [...] os processos seguidos até aqui pela imprensa de nossa terra, entregou-se de corpo e alma a esse desideratum" (p. 1). Em seguida, destacava que "emprestando [...] com todo o fulgor de seu talento, laboriosa e eficiente colaboração ao CRUZEIRO, órgão daquela entidade, eram imensamente apreciados seus magistrais artigos de fundo, verdadeira fonte de ensinamentos profundamente morais" (p. 1).

Nas edições seguintes do Diário da Tarde não localizamos nenhum comentário a respeito das publicações da edição do Cruzeiro de 31 de outubro. Porém, o jornal católico publicou no dia 01 de novembro uma nota no alto da primeira página informando ao leitor que foi ingressado à $3^{\mathrm{a}}$. Vara Criminal, com um processo crime contra os diretores dos jornais Diário da Tarde e A Tarde, assinado por quinze advogados vinculados à Igreja Católica. No editorial dessa edição, sob o título "nossa atitude", os católicos explicam as razões do ingresso judicial contra os responsáveis pelos jornais que veicularam acusação contra Miele. Entre as várias argumentações, destaco que "o verdadeiro jornalismo [...] tem uma missão mais elevada que a de criar fantasias e histórias bordadas pela forja imaginária das lendas românticas, ou trágicas, [...] relatadas por quem se mostra ou se apresenta com interesse visível no caso" (CRUZEIRO, 1 nov. 1931, p. 1). Em seguida, reafirma: "o nosso papel tem sido o de rebater a maldade viperina, nos efeitos de uma acusação infamante que se mostra sem fundamentos provados" (p. 1). Destaca que "a prevalecer sem contestação no espírito público, seria o predomínio do regime da tirania de letra de forma' sem mais defesa da razão imparcial que a todos deve assistir" (p. 1). Porém, acrescenta que após o debate público, "a defesa - essa compete doravante aos patronos jurídicos do acusado; e a justiça aos juízos soberanos e impolutos de nossa terra” (p. 1).

Posteriormente ao confronto de acusação e defesa estampado nas páginas do matutino e vespertino, o debate entre Diário da Tarde e Cruzeiro assumiu duas frentes: 1) debate jurídico em torno do processo crime instaurado pelos católicos contra os anticlericais; 2) discussão sobre a natureza da imprensa. Os dois jornais publicavam textos em linguagem jurídica, portanto, escritos pelos próprios advogados das partes para fundamentar e justificar as razões do querelante (Pe. Miele) e do querelado (Rodrigo de Freitas). Outra estratégia discursiva foi a preocupação em debater sobre o papel da imprensa. Essas ações, em minha avaliação, sintetizam o confronto entre católicos e anticlericais nas edições de dezembro de 1931 a janeiro de 1932. 
O Diário da Tarde publicou longos escritos nas edições do mês de dezembro, ${ }^{6}$ nos quais apresentava seus argumentos jurídicos e filosóficos em defesa do querelado. Após longa disputa na $3^{\text {a }}$. Vara Criminal, acompanhada de publicações no Diário da Tarde, o grupo anticlerical estampou na edição de 26 de dezembro: "vitória da Justiça! O íntegro e ilustre Juiz da Terceira Vara Criminal anulou o processo intentado contra Rodrigo de Freitas, diretor do 'Diário da Tarde'. Apesar da demonstração de força dos 'quinze maiores juristas do Paraná' venceu a justiça e triunfou o direito” (DIÁRIO DA TARDE, 26 dez. 1931, p. 1).

Por outro lado, os católicos também publicavam suas argumentações jurídicas apresentadas pelos juristas católicos. ${ }^{7}$ Nas edições de 17, 18, 19 e 20 de dezembro, por meio do título "as brilhantes alegações do querelante pelo advogado Sr. Dr. Manoel de Lacerda Pinto", os católicos responderam ao pedido de anulação do processo crime instaurado contra os diretores dos vespertinos A Tarde e Diário da Tarde. No dia 27 de dezembro, o matutino católico publicou uma nota sobre a anulação do processo: "a sentença proferida [...] anulando o processo intentado [...] contra os diretores da A Tarde e Diário da Tarde [...] não constitui decisão definitiva nem assinala a vitória apregoada pelos querelados" (CRUZEIRO, $27 \mathrm{dez}$. 1931, p. 1). Na edição de 01 de janeiro de 1932, o grupo católico manifestou-se em nota que "os advogados do padre Miele, não se conformando com a anulação, pelos motivos aludidos em um dos editoriais do Cruzeiro, ${ }^{8}$ [...] apelaram da decisão para o Superior Tribunal de Justiça do Estado" (CRUZEIRO, 1 jan. 1932, p. 1). Na edição de 12 de janeiro de 1931, o matutino católico publicou uma nota informativa sobre a apelação impetrada pelos advogados católicos, cuja argumentação, sob o título "razões de apelação apresentadas ao Superior Tribunal de Justiça do Estado pelos Drs. Homero Batista de Barros e José Farani Mansur Guérios", foi transcrita nas edições de treze, dezesseis, dezessete e dezenove de janeiro daquele ano. ${ }^{9}$

O confronto entre católicos e anticlericais avança para o campo jurídico. A disputa ocorria na arena pública, na imprensa. Porém, o próprio debate jornalístico fazia-se sob a linguagem jurídica. Neste texto, pactuo com a afirmação de Bourdieu (2002, p. 212) de que "o campo jurídico é o lugar de concorrência pelo monopólio do direito de dizer o direito, quer dizer, a boa distribuição (nomos) ou a boa ordem, na qual se defrontam agentes investidos de competência ao mesmo tempo social e técnica [...]". O aspecto recorrente na argumentação de católicos e anticlericais é a afirmação da tese da neutralidade jurídica. A ideia de que "a situação judicial funciona como lugar neutro, que opera uma verdadeira neutralização das coisas em jogo por meio da defrontação directa dos interessados em diálogo entre mediadores" (BOURDIEU, 2002, p. 227, grifo do autor), é útil para explicar as argumentações jurídicas apresentadas pelos grupos do Cruzeiro e Diário da Tarde.

6 O Diário da Tarde publicou textos de análise jurídica nas edições de 09, 10, 11, 12, 14, 15, 16, 17 e 26 de dezembro de 1931. 7 O Cruzeiro publicou textos de análise jurídica nas edições de 01 de novembro, 17, 18, 19, 27 e 29 de dezembro de 1931, bem como de 01, 03, 06, 12, 13, 16, 17, 19, 20, 21, 22 e 27 de janeiro de 1932.

8 A discussão dos motivos da anulação do processo foi feita no editorial de 29 de dezembro de 1931.

90 matutino católico publicou nas edições de 21,22 e 27 matérias sobre os equívocos da anulação do processo, assim como em relação à apelação. No final de janeiro de 1931, o Cruzeiro deixa de circular, portanto esse debate entre clericais e anticlericais sai da cena jornalística. 
Do ponto de vista filosófico, o argumento dos anticlericais aludiu ao direito de liberdade do jornalista. Além disso, sobrepôs ao debate jurídico o aspecto moral quando buscou recuperar a afirmação de Plínio Barreto: "ao querelante deverá interessar menos a punição do seu agressor, do que a atestação pública e decisiva da sua honestidade, profissional, posta em dúvida pelo réu" (DIÁRIO DA TARDE, 9 dez. 1931, p. 1). Tal observação pretendia desqualificar o grupo católico por ter transferido o debate jornalístico para a esfera judicial. O grupo anticlerical arrematava esse aspecto ao indicar: "podem [os querelados] ir para a cadeia. Mas, sobre o nome do Padre Miele ficará sempre [...] a dúvida que ele mesmo gerou em todos os espíritos [...] que ainda sabem conciliar a religião com a liberdade de análise e não se deixaram enredar no fanatismo" (p. 1). É interessante observar que aos católicos, "as liberdades individuais deveriam receber uma limitação proporcional ao seu grau de importância" (CRUZEIRO, 8 nov. 1931, p. 1). Ao grupo clerical, o grau de importância "mede-se pela maior ou menor influência do exercício dessa liberdade na esfera de uma atividade alheia. E eu vos pergunto, de todas as liberdades, não será a de imprensa a mais perigosa?" (p. 1).

Os católicos buscavam estabelecer uma diferenciação entre boa e má imprensa. No editorial, o Cruzeiro assevera: "o povo de cada localidade tem a imprensa que merece. Ela é o reflexo dos seus sentimentos, dos seus ideais, do seu caráter, da sua moral e da sua religião" (CRUZEIRO, 7 nov. 1931, p. 1). E arrematava: "tal povo, tal imprensa. E, como em toda parte há bons e maus, também há boa e má imprensa em toda parte” (p. 1). Para os católicos, a boa imprensa é o "farol que ilumina os homens na tortuosa vereda desta vida [...]. É guia seguro que conduz ao porto almejado" (CRUZEIRO, 7 nov. 1931, p. 1). Por outro lado, "a má imprensa é perigo constante que oferece aos nautas o desastre e a morte" (p. 1). Em termos comparativos, "luzeiros são os dirigentes da boa imprensa, ao passo que são cegos, e guias de cegos, os timoneiros da imprensa má" (p. 1). Para os clericais, a boa imprensa "protege os bons contra as ciladas dos maus [...], sublima a autoridade que vem de Deus [...], propaga os bons princípios e lança no seio da sociedade e da família os germes de uma vida pura e suave [...]" (p. 1). Porém, a má imprensa "é o órgão insolente das objurgatorias dos perversos, dos incitamentos perturbadores dos demagogos revolucionários, dos demolidores do princípio da autoridade, dos elementos turbulentos da insubordinação e da desordem, das injustiças [...]" (p. 1). Ademais, a imprensa má é a porta voz "dos insufladores de ódio e vinganças, os quais todos implantam o desequilíbrio na sociedade e na família [...]" (p. 1). A imprensa ímpia revolve "a lama da mentira, da injúria e da calúnia para atirá-la nos caracteres impolutos, denegrindo a honra, infamando o nome, expondo ao desprezo público os homens de sentimentos nobres, de vida exemplar, de proceder ilibado e intemerato" (p. 1).

Na imprensa má, no entendimento católico, "imprime-se a calúnia, escrita em linguagem de cafajeste, com barbarismos e solecismos dos mais grados. A gente sensata que lê não dá crédito à infâmia. Mas os estultos acreditam em tudo. Para eles, é como se tivessem 
visto" (p. 1). Desse modo, "a notícia espalha-se, como toda a notícia má, com a rapidez do raio. E dentro de breve se cria e se forma uma opinião inabalável" (p. 1).

Na edição do dia seguinte (8 de novembro), o Cruzeiro publicou uma parte da conferência de Laerte Munhoz, sob o título "a ética profissional do jornalista". A referida conferência foi feita na Associação Paranaense de Imprensa, pelo jornalista já denominado que fazia parte do grupo católico. Da publicação, cabe destacar: "ao exercício desse poder, que é a imprensa, devem ser chamados homens que estejam na altura dele" (CRUZEIRO, 8 nov. 1931, p. 1). A imprensa, reiterou o conferencista, "há de ser dirigida e confiada por quem, pela imparcialidade de suas normas, pelo privilégio da sua cultura e pela puridade de seu caráter, tenha conquistado o direito de invadir as esferas de alheias atividades" (CRUZEIRO, 8 nov. 1931, p. 1). Em sentido específico, sustentou que "a ética profissional do jornalista é o filtro de todas as impurezas, de todos os males, de todos os bacilos da perfídia e da perversidade, que, de forma nenhuma, devem atingir as colunas dos jornais [...]" (p. 1). Ressaltou que as notícias jornalísticas deveriam ser pautadas em fatos e evidências, pois a especulação não pode conduzir a prática da imprensa. Para o matutino, "quando [...] predomina apenas a especulação do escândalo, a ambição material de fabricar casos sensacionais, [...] o jornal deixa de ser o instrumento de uma liberdade, para se tornar uma verdadeira indústria, a indústria da infâmia" (p. 1). Por fim, ressaltou que o jornalismo não deve "[...] explorar escândalos, [...] fazer casos sensacionais, para, iludindo os incautos, obter uma maior tiragem" (p. 1). Porém, acrescentou o jornalista católico, "o jornal deve ser um livro de ensinamentos coligidos através das notícias dos fatos" (p. 1).

As descrições dos fragmentos dos jornais estão sistematizadas a luz da hipótese de que católicos e anticlericais estabeleciam um conjunto de instituições para se lançarem no cenário cultural e político. Essas intervenções estavam relacionadas às mudanças ocorridas entre o século XIX e século XX, particularmente ao avanço das posições, genericamente chamadas de seculares e as reações do movimento católico.

Esses posicionamentos ganharam força no Brasil, a partir da segunda metade do século XIX $^{10}$. Do mesmo modo, no Paraná ${ }^{11}$. Em 27 de abril de 1892, Leão XIII criou a Diocese de Curitiba. Porém, ela foi instalada em 30 de setembro de 1894 com a posse de Dom José Camargo de Barros. Havia grande interesse por parte da Igreja Católica na formação da Diocese de Curitiba, pois junto com os imigrantes europeus veio uma diversidade de correntes teóricas, como por exemplo, anarquistas, sindicalistas, socialistas, positivistas, liberais.

10 Consultar Sergio Micelli (1974); Augustin Wernet (1983); José Beozzo (1984); Roque S. Barros (1986); Euclides Marchi (1989); Scott Mainwaring (1989); Roberto Romano (1991); Romualdo Dias (1993); Élio Serpa (1997); Marta Carvalho (1998); Marcus L. Bencostta (1999); Diogo Cavalheiro (2001); Marcos Gonçalves (2008); Ramiro Oliveira (2010).

11 Consultar Maria Lucia Andrade (2002); Tatiana Marchette (1999); Carlos Balhana (1981); Névio de Campos (2010); Etelvina Trindade (1996). 
As ideias modernas estavam presentes entre o grupo que se denominava representante do pensamento laico. Com a criação da Diocese de Curitiba, a igreja acreditava que constituía um importante elemento de reação aos anticlericais que já estavam presentes no cenário cultural paranaense, bem como uma instituição que se colocava com a missão de organizar o clero e o laicato católico para divulgar a doutrina católica. É possível afirmar que o ambiente cultural paranaense era marcado por disputa pela formação das novas gerações, particularmente entre intelectuais que se denominavam livres-pensadores e clericais.

No Paraná, o projeto do grupo anticlerical visava promover uma crítica ao poder do clero local. Esse grupo contrapunha-se aos católicos e queria disputar os espaços de formação da juventude e da intelectualidade curitibana. Nesse estado, as correntes de ideias modernas tiveram suas raízes nos movimentos abolicionistas de 1870 , nos propagandistas pró-republicanos, no Clube Republicano de Curitiba, fundado em 1885, por Eduardo Mendes Gonçalves, nos jornais liberais, dentre os quais destaco Diário da Tarde e Tarde.

Tal confronto se materializou no campo educacional, no campo literário e na imprensa. Neste texto, explorei a disputa entre anticlericais (Diário da Tarde) e católicos (Cruzeiro). Os livres-pensadores se posicionavam "contra os reacionários, ultra-montanos, jesuitismo dissolvente, clericalismo rasteiro, contra, enfim, todos os inimigos da Razão, da Ciência, do Progresso, da Justiça, da Caridade, da Liberdade, da Família, da Pátria, e da Humanidade" (BALHANA, 1981, p. 22). Por outro lado, os clericais estabeleceram a imprensa católica para divulgar sua doutrina religiosa e desconstruir a iniciativa anticlerical.

A partir de 1920, a reação da Igreja Católica assumiu um papel decisivo. Até então, a igreja estava organizando-se internamente, pois para estabelecer o seu programa de reação ao laicismo se fazia necessário criar um clero combatente e comprometido com as diretrizes da romanização. Na década de vinte foram criados, no Rio de Janeiro, o Centro Dom Vital, a revista A Ordem. Nos anos trinta a Liga Eleitoral Católica, a Confederação Católica Brasileira de Educação (CCBE) e muitos outros. No Estado do Paraná, a hierarquia da igreja orientou a criação da União de Moços Católicos de Curitiba, a imprensa católica, o Círculo de Estudos Bandeirantes e a Faculdade de Filosofia, Ciências e Letras. Para atingir tal estágio de organização, a Igreja Católica vinha agindo desde meados do século XIX com o objetivo de constituir seu grupo para combater os anticlericais e divulgar as suas ideias na sociedade brasileira.

O que se configurava no plano do debate e da disputa entre os livres-pensadores e o laicato católico refletia-se nas ações políticas dos governadores do Paraná. Romário Martins na sua obra História do Paraná (1939) afirma que vários governadores adotaram, ao longo da história do Paraná, os termos ordem e progresso como slogans que indicavam as diretrizes de suas administrações. Não obstante, alguns governantes tentaram conciliar a ordem e o progresso, termos do léxico positivista, garantindo apoio às ideias católicas, como por exemplo, o governo de Francisco Xavier da Silva que auxiliou tanto a instrução de iniciativa 
pública como a de iniciativa privada, particularmente as escolas confessionais católicas. Outro elemento que indica o apoio ao grupo católico é o afastamento do professor Dario Vellozo da cátedra do Ginásio Paranaense e da Escola Normal, por ato do governador Xavier da Silva, em 1909. Por outro lado, conforme Romário Martins, grande parte dos governantes paranaenses simpatizava e apoiava o movimento do grupo anticlerical, entre os quais destaco Mario Tourinho, Sebastião Paraná, Emiliano Perneta e Ermelino de Leão. De acordo com Erasmo Pilotto, tais personalidades "faziam parte da comissão do 'Centro de Estudos Esotéricos Luz Invisível', fundada em 1900 e dirigida por Dario Vellozo” (PILOTTO, 1976, p. 458-459).

As observações em tela ajudam a compreender o contexto histórico do Paraná da época. De um lado, começou o processo de formação do grupo dos anticlericais, também chamado de livres-pensadores. De outro, a formação do grupo dos pensadores católicos que postulava a necessidade de estudar e divulgar a doutrina católica entre a população curitibana, contribuindo, assim, com o projeto romanizador. O grupo católico leigo foi estruturado posteriormente ao movimento anticlerical, isto é, o grupo dos livres-pensadores provocou a organização do laicato católico no Paraná.

A Ação Católica foi postulada por Pio XI com o objetivo de combater o laicismo e disseminar os princípios do catolicismo. Nesse movimento, a imprensa deveria cumprir seu papel, pois, conforme Gramsci (2001, p. 198), "em sentido lato, o jornal 'católico' (ou sobretudo 'escrito por católicos') é o que não contém nada contra a doutrina e a moral católicas, e segue e defende suas normas". Por outro lado, em sentido estrito "é o que, de acordo com a autoridade eclesiástica, tem como finalidade direta um eficaz apostolado social cristão, a serviço da Igreja e em apoio à Ação Católica" (GRAMSCI, 2001, p. 198-199). Desse modo, a imprensa católica cumpria uma tarefa importante nesse processo de propagação dos valores católicos entre os leitores ${ }^{12}$.

\section{Considerações finais}

A discussão deste texto privilegiou a ação pública dos intelectuais católicos e anticlericais. Dessa forma, enfatizou o aspecto mediático dos intelectuais paranaenses. Tal abordagem ressaltou uma faceta do intelectual: que ele "existe na e pela mídia. Suas petições, seus manifestos, mesmo suas obras devem passar pelo canal da mídia (imprensa, revistas, TV etc.)" (LECLERC, 2005, p. 88). A outra face do intelectual é a sua produção cultural, filosófica, científica. Em geral, tais condições estão associadas, pois o pertencimento ao campo cultural (artístico, científico, filosófico) é um elemento 
fundamental para sua inserção no domínio da opinião pública, pois o jornal "[...] entendido como lugar de produção, veiculação e circulação dos discursos - assume uma função importante no processo de formação das representações sobre o mundo" (VIEIRA, 2007b, p. 16).

Esta narrativa explorou a dimensão midiática, portanto, a ação dos intelectuais no processo de formação da opinião pública paranaense. Nesse sentido, "o jornal impresso diário é parte de uma estrutura midiática de enorme impacto e cada vez mais, diversificada ação política e cultural" (VIEIRA, 2007b, p. 14). Isto é, de acordo com Carlos Eduardo Vieira, "a imprensa permite uma ampla visada da experiência citadina: dos personagens ilustres aos anônimos, do plano público ao privado, do político ao econômico, do cotidiano ao evento, da segurança pública às esferas cultural e educacional" (p. 13). As personalidades que dirigiam o Diário da Tarde e o Cruzeiro podem ser denominados intelectuais, pois "são eloquentes, fazedores de discursos dos mais variados gêneros. Afinal, são homens do espaço público, no sentido histórico, sociológico e simbólico [...]" (LECLERC, 2005, p. 12).

A condição de um intelectual não se define por uma razão essencialista. Neste texto, a hipótese de Gramsci (2001, p. 18) de que "todos os homens são intelectuais, mas nem todos os homens têm na sociedade a função de intelectuais [...]" mostrou-se uma fecunda chave de interpretação. É a atividade social de um indivíduo que define sua condição de intelectual. Dessa forma, é possível sustentar que a ação pública de católicos e anticlericais que resultou na criação de jornais e na produção de textos, objetivando formar uma opinião pública, evidencia o sentido da função do intelectual inaugurado pelo caso Dreyfus, no final do século XIX.

A chamada opinião pública não é recente no jornalismo e suas principais características datam das duas primeiras décadas do século XVIII na Europa. Carlos Eduardo Vieira argumenta que o conceito de opinião pública está associado à questão da modernidade. Partindo desse princípio, conforme Vieira (2007b, p. 19), "a modernidade foi concebida pelos seus principais arautos como a ação edificante da razão que - por meio da ciência, da tecnologia, da instrução e das políticas sociais - universalizaria um novo modo de pensar e agir." Nesse aspecto, os jornais representariam um importante aliado, não só no papel de incentivador de manifestações culturais, como ainda exerceriam a importante função de polemização. Por isso, a imagem da imprensa, tanto ontem como hoje, está associada ao seu poder de formar a chamada opinião pública. Segundo Peter Burke e Asa Briggs, "genericamente, os jornais contribuíram para o aparecimento da opinião pública, termo que tem seu primeiro registro em francês por volta de 1750, em inglês em 1781; e em alemão, em 1793." (2006, p. 78).

É possível definir opinião pública como a tentativa de universalização de um novo modo de pensar e agir. A assertiva de Gramsci (2001, p. 209), "todo estrato social tem seu 'senso comum' e seu 'bom senso', que são, no fundo, a concepção da vida e do homem 
mais difundida" sintetiza a acepção de opinião pública. Para ele (p. 209), "toda corrente filosófica deixa uma sedimentação de 'senso comum': é este o documento de sua efetividade histórica. O senso comum não é algo rígido e imóvel, mas se transforma continuamente, enriquecendo-se com noções científicas e com opiniões filosóficas que penetrarem no costume".

Concluindo, a condição flexível e móvel da opinião pública explica as razões das cruzadas de católicos e anticlericais na capital do Paraná, pois se tratava de conformar modos de pensar e agir a partir de cosmovisões divergentes. Portanto, as polêmicas, acusações, defesas, bem como os manifestos, debates e confrontos entre católicos e anticlericais tomavam colorações diversas, porém, suas estratégias e táticas buscavam catolicizar ou secularizar a opinião pública paranaense.

\section{Referências}

A CRUZADA (Revista mensal da mocidade católica paranaense). Curitiba, 1926-1931.

ANDRADE, Maria Lúcia de. Educação, cultura e modernidade: o projeto formativo de Dario Vellozo (1906-1918). 2002, 170 f. Dissertação (Mestrado em Educação) - Programa de PósGraduação em Educação, Universidade Federal do Paraná, Curitiba, 2002.

BALHANA, Carlos Alberto. Idéias em confronto. Curitiba: Grafipar, 1981.

BARROS, Roque Spencer Maciel de. A ilustração brasileira e a idéia de universidade. São Paulo: Edusp, 1986.

BENCOSTTA, Marcus Levy Albino. Igreja e poder em São Paulo: D. João Batista Corrêa Nery e a romanização do catolicismo brasileiro (1908-1920). 1999. Tese (Doutorado em História) Universidade de São Paulo, São Paulo, 1999.

BEOZZO, José Oscar. A igreja entre a revolução de 1930, o estado novo e a redemocratização. In: FAUSTO, Boris. (Org.). O Brasil republicano: economia e política (1930-1964). São Paulo: DIFEL, 1984, p. 271-341.

BURKE, Peter; BRIGGS, Asa. Uma história social da mídia: de Gutenberg à internet. Rio de janeiro: Zahar, 2006.

BOURDIEU, Pierre. O poder simbólico. Rio de Janeiro: Bertrand Brasil, 2002. 
CAMPOS, Névio de. Intelectuais e igreja católica no Paraná: 1926-1938. Ponta Grossa: UEPG, 2010.

CARVALHO, Carlos Henrique de; GONÇALVES NETO, Wenceslau. Educação, religião e república: repercussões dos debates entre católicos e republicanos no Triângulo Mineiro-MG (1892-1931). História da Educação, Pelotas, vol.10, n. 19, p. 59-88, abr. 2006.

CARVALHO, Marta Maria Chagas de. Molde nacional e fôrma cívica: higiene, moral e trabalho no projeto da Associação Brasileira de Educação (1924-1931). Bragança Paulista: EDUSF, 1998.

CAVALHEIRO, Diogo. Hegemonia católica e educação da elite em Itu (1851-1889): o Colégio do Patrocínio e o Colégio de São Luiz de Gonzaga. 2001. Tese (Doutorado em Educação) Unimep, Piracicaba, 2001.

CRUZEIRO (Jornal da Legião Paranaense de Boa Imprensa). Curitiba, 1931-1932.

DIÁRIO DA TARDE. Curitiba, 1899-1975.

DIAS, Romualdo. Cor unum et anima uma. A doutrina católica sobre a autoridade no Brasil (1922-1935). 1993, 285 f. Tese (Doutorado em Lógica e Filosofia da Ciência) - Universidade Estadual de Campinas, Campinas, 1993.

GONÇALVES, Marcos. Missionários da 'boa imprensa': a revista Ave Maria e os desafios da imprensa católica nos primeiros anos do século XX. Revista Brasileira de História, São Paulo, vol. 28, n. 55, p. 63-84, jan./jun. 2008.

GRAMSCI, Antonio. Cadernos do cárcere. Vol 2. Rio de Janeiro: Civilização Brasileira, 2001.

LECLERC, Gerard. Sociologia dos intelectuais. São Leopoldo: Unisinos, 2005.

MAINWARING, Scott. Igreja católica e política no Brasil (1916-1985). São Paulo: Brasiliense, 1989.

MARCHETTE, Tatiana Dantas. Corvos nos galhos das acácias: o movimento anticlerical em Curitiba (1896-1912), Curitiba: Aos Quatro Ventos, 1999.

MARCHI, Euclides. A igreja e a questão social: o discurso e a práxis do catolicismo no Brasil (18150-1915). São Paulo, 1989. Tese (Doutorado em História) - Universidade de São Paulo, São Paulo, 1989.

MARTINS, Romário. História do Paraná. São Paulo: Rumo Ltda, 1939.

MICELI, Sérgio. A elite eclesiástica brasileira. Rio de Janeiro: Bertrand Brasil, 1974. 
OLIVEIRA, Ramiro de. O conservadorismo católico na imprensa de Belo Horizonte nas décadas de 1920 e 1930 - os jornais o Horizonte e o Diário (1923-1937). 2010, 161 f. Dissertação (Mestrado em História) - Programa de Pós-Graduação em História, Universidade Federal de São João Del-Rei, São João Del-Rei, 2010.

PAZ, Francisco Moraes. Utopia e modernidade: a nostalgia da transparência. In: (Org.). Utopia e modernidade. Curitiba: UFPR, 1994.

PILOTTO, Erasmo. Obras - Mallarmé, Notas sobre Spinoza, Poeria do Quotidiano, Estudos Paranaenses (Emiliano, Dario Vellozo, João Turim, Th. De Bona). Tomo II. Curitiba: Composto e impresso em Imprimax Ltda, 1976.

PRETTO, Juliana. A notícia sensacionalista como um gênero textual. 2006, 127 f. Dissertação (Mestrado em Estudos Lingüísticos) - Curso de pós-graduação em Letras, Universidade Federal do Paraná, Curitiba, 2006..

REVISTA DO CÍRCULO de Estudos Bandeirantes. Curitiba, 1934-1954.

ROMANO, Roberto. Brasil: igreja contra estado (crítica ao populismo católico). São Paulo: Koirós, 1991.

SERPA, Élio C. Igreja e poder em Santa Catarina. Florianópolis: UFSC, 1997.

TRINDADE, Etelvina Maria de Castro. Clotildes ou Marias: mulheres de Curitiba na Primeira República. Curitiba: Fundação Cultural, 1996.

VIEIRA, Carlos Eduardo. (Org.). Intelectuais, educação e modernidade no Paraná (1886-1964). Curitiba: UFPR, 2007a.

VIEIRA, Carlos Eduardo. Jornal diário como fonte e como tema para a pesquisa em história da educação: um estudo da relação entre imprensa, intelectuais e modernidade nos anos de 1920. In: OLIVEIRA, Marcus Aurélio Taborda de. Cinco estudos em história e historiografia da educação. Belo Horizonte: Autêntica, 2007b, p. 11-40.

WENET, Augustin. A igreja paulista no início do século XIX. São Paulo: Ática, 1983. 